\title{
Rusland og Syrien set fra Letland
}

\section{Af Jānis Kažocinš}

Ruslands handlinger er uforudsigelige. Putin er en opportunist, der har formået at overraske Vesten på Krim og nu i Syrien. Men denne formodede succes og Vestens manglende vilje til at konfrontere Rusland øger risikoen for fejlberegning med vidtrækkende konsekvenser. Putins mål er at forblive ved magten så længe som muligt. På baggrund af de aktuelle økonomiske forhold og nedturen som følge heraf $i$ selve Rusland kan dette bedst opnås ved at forfølge eksterne fjender.

I marts 2014 besatte og derefter annekterede Rusland Krimhalvøen i en mesterlig og ublodig udført militær operation. Dette blev derefter hurtigt fulgt op af et uovervejet og blodigt eventyr ind i Donbas. Begge begivenheder gjorde et dybt indtryk på det lettiske samfund. I marts 2013 havde Ruslands præsident Putin fortalt det militærhistoriske samfund ved Novo-Ogaryovo, at Sovjetunionen havde initieret Vinterkrigen mod Finland for at 'rette op på historiske fejltagelser' som Finland havde opnået ved sin uafhængighed i 1917. "Grænsen var bare $20 \mathrm{~km}$ fra St. Petersborg og det udgør en betydelig trussel mod en by med fem millioner ind- byggere”. Dertil kommer, at det er almen kendt, at Putin anså Sovjetunionens sammenbrud for 'en af århundredets store geopolitiske katastrofer'.

Tilsammen sendte disse kendsgerninger og udtalelser kuldegysninger gennem det lettiske samfund, og mange samtaler rundt om spisebordene i de sidste dage af 2014 handlede om planer for, hvad man skulle gøre, hvis Rusland invaderede Letland og de andre baltiske stater: Estland og Litauen. Gradvist blev disse bekymringer dog formindsket i takt med, at NATO kom til live; tilstedeværelsen af allierede styrker på baltisk territorium gav en vis grad af tryghed, sammenholdt med de kategoriske solidaritetserklæringer fra mange allierede ledere og i særdeleshed fra Præsident Obama. Men ikke desto mindre kunne frygten ikke fjernes helt. De allieredes tilstedeværelse var forholdsvis lille selv sammenholdt med vores egne fă og kun let bevæbnede militære styrker og kunne ikke opfattes som reelt afskrækkende over for et genmilitariseret Rusland parat til at engagere sig i alvorlige militære eventyr.

\section{Hvad er forandret?}

Siden 2014 bliver det mere og mere tydeligt, at der ikke er en militær løsning på

Jānis Kažocinš er tidligere direktør i the Latvian Constitution Protection Bureau. 
krigen i Ukraine. På den ene side har Rusland demonstreret, at Rusland er parat til at være militært tilstede i et omfang, der kan fratage Ukraine den militære sejr. På den anden side er Rusland ikke engang parat til at afsætte den nødvendige militære kapacitet til at sikre en landbro til Krimhalvøen endsige at opnå et Nyrussisk (Novaja Rossija) kimære. Hvis Rusland intensiverer de militære operationer i Donbas, så bortvejrer det myten om at krigen i Donbas udkæmpes af modige lokale separatister støttet af få men patriotiske russiske frivillige. Det ville ligeledes kræve, at man er i stand til at holde området belejret mod en langt mere kompetent ukrainske hær i et fjendtligt miljø. Det vil medføre flere russiske krigsofre, hvilket for tiden er en sensitiv sag for Kreml. Endelig vil mere alvorlige vestlige sanktioner underminere den stagnerende russiske økonomi yderligere.

Men Putin kan heller ikke trække sig fra kampene i Ukraine, da dette vil blive opfattet som et forræderi mod de patriotiske russere, som har kæmpet i Ukraine. Det ville ligeledes betyde, at man ville være nødsaget til at tilbagerulle den fortælling om krigen, som så omhyggeligt er blevet skabt af især det russiske statsfjernsyn. Derudover ville det vise en svag Putin - hvilket kan være dødeligt for hans hold om magten. Samtidig blev en ny scene for russiske militære operationer både presserende og tiltrækkende: Syrien.

Syrien har været Ruslands allierede siden 1956. Flådebasen Tartus er helt essentiel for russiske magtdemonstrationer i Middelhavet, og den var sammen med Lataku luftbasen i øget omfang truet under angreb fra de syriske oppositionsstyrker. Præsident Bashar al-Assad er ifølge russerne den syriske stats legitime leder, og derfor vil Rusland anse ethvert forsøg på at fjerne ham med magt for terrorisme.

Ruslands militære deltagelse i den syriske konflikt har også som formål at vise, at Rusland er tilbage på verdens scene som mere end bare en regional supermagt: nu er alle som ønsker fred i Mellemøsten nødt til at indregne Ruslands tilstedeværelse og synspunkter. Endelig, vil Ruslands deltagelse i den internationale krig mod terrorisme kunne distrahere og flytte opmærksomheden væk fra Ukrainekrisen. Det var derfor, at det Russiske Føderationsråd i september 2015 godkendte anvendelsen af de russiske væbnede styrker i Syrien til at bekæmpe militante grupper på anmodning fra den syriske præsident.

Dette krævede omfattende luft-, flådeog landkapacitet, der kunne indsættes øjeblikkeligt. I skrivende stund er det oprindelige omfang på omkring 2.000 mænd vokset til 40.000 mænd og med 36 fly og 20 angrebshelikoptere. Der er rapporter om, at specialstyrker er blevet trukket tilbage fra det østlige Ukraine med henblik på at blive indsat i Syrien. Dette synes at være i overensstemmelse med den nedsatte aktivitet $\mathrm{i}$ kamphandlingerne dér.

Logistik spiller en meget vigtig rolle i Ruslands tungt bevæbnede krigsførelse i Syrien. Det er meget bekosteligt både i form af de våben, der anvendes, og i forhold til transportbehov. Det er vigtigt at være opmærksom på, at en rundtur over havet fra Krimhalvøen til Tartus tager ca. 10 dage. Det indebærer ligeledes store omkostninger at transportere og bakke logistisk op via luften. Luftangreb koster Moskva op imod 4 millioner US dollar om dagen, og bombardementer, forsyningskørsel, infrastruktur og landpersonel sammen med salver af krydsermissiler affyret ind i konfliktzonen har kostet Rusland mellem 80 til 115 millioner US dollar i perioden fra 30 . september til 
Hvis Daesh eller andre islamiske grupper ikke er i stand til at beskytte sig selv mod luftangreb, så er det ikke overraskende, hvis de ville søge at angribe fjendens befolkning. Parisangrebet demonstrerede, at gengældelsesangreb sandsynligvis vil finde sted på fjendens hjemmebane.

20. oktober 2015. Disse ekstra omkostninger vil ikke fremme den modernisering af de russiske bevæbnede styrker, der er planlagt til at være afsluttet i 2020, men som formentlig vil komme til at tage længere tid.

\section{Blandede følelser}

Alle væbnede styrker ønsker at få lejlighed til af afprøve deres nyeste legetøj. Russerne er ingen undtagelse og har benyttet sig af den syriske scene til at sende beskeder til deres venlige og mindre venlige naboer om, hvilken militærkapacitet Rusland kan bringe i anvendelse. For eksempel er de fleste vestlige kommentatorer overrasket over anvendelsen af krydsermissiler mod syriske mål. Det kan godt være at USA har grund til at tro, at ud af de 26 krydsermissiler affyret fra Ruslands Kaspiske flåde landede fire i Iran, men de viste samtidig, at de russiske væbnede styrker har nået et imponerende højt teknologisk udviklingsniveau.

Men ligeledes ønsker enhver professionel senior militærchef, at hans politiske herre informerer om, hvad definitionen på succes er, og hvad exit-strategien er. Det er spørgsmål, som Kreml har svært ved at svare på. Det er ikke tilfældigt, at de vestlige magter er gået af vejen for at undgå militære udstationeringer i Syrien og indtil fornylig undgå direkte konfrontationer med Daesh (ISIS/ISIL). Den 2. oktober advarede præsident Obama Rusland om, at Ruslands bombardementer mod de syriske rebeller ville trække Moskva ned i 'hængedyndet'.

I skrivende stund er omfanget af russiske krigsofre ukendt. Men det ville være for optimistisk at forvente at Daesh og den syriske opposition vil finde sig i russiske luftoffensiver uden nogen form for gengældelse. Det så man ganske tydeligt, da russerne endelig indrømmede, at det russiske fly, som faldt ned over Sinai-halvøen den 31. oktober, havde været mål for en terrorhandling. Hvis russiske statsborgere bliver dræbt som gengældelse, vil det blive svært at retfærdiggøre forsvaret af Rusland i fjerne egne.

De tragiske angreb i Paris den 13. november tjener til at understrege den hjemlige trussel. Antallet af muslimer i Rusland er estimeret til mellem 6 pct. og 14 pct. af befolkningen svarende til mellem 8 og 19 mio., hvoraf hovedparten er sunnimuslimer og ca. 5 pct. shiamuslimer. Ifølge al Jazeera er Moskva hjemsted for 1,5 mio muslimer ud af en befolkning på officielt 12,5 mio. Man kan kun forestille sig deres reaktioner på ærkepræst Vsevolod Chaplins udtalelser om, at Ruslands handlinger i Syrien skal ses som et led i en hellig kamp mod terrorisme. Hvis Daesh eller andre islamiske grupper ikke er i stand til at beskytte sig selv mod luftangreb, så er det ikke overraskende, hvis de ville søge at angribe fjendens befolkning. Parisangrebet demonstrerede, at gengældelsesangreb sandsynligvis vil finde sted på fjendens hjemmebane.

\section{Kapacitet og intentioner}

Rusland har gjort store fremskridt og accepteret store ofre for at forbedre sin militære kapacitet, siden den russiske hære leverede en meget ringe præstation i den georgiske krig i 2008; og finansiering til sundhedssektor og uddannelse, som al- 
drig har haft topprioritet, har måttet holde for. Man kunne allerede se resultatet i de kvalitative forbedringer i for eksempel militærøvelsen Zapad ('vest') 2013/14 sammenlignet med øvelsen Zapad 2009. Ruslands operation på Krimhalvøen og Ruslands påviselige evne til at indsætte styrker i Mellemøsten parallelt med fornyelsen af den atomare kapabilitet og strategiske mobilitet peger alt sammen på en afgørende og vægtig forbedring i den militære kapacitet.

Det tager lang tid at oparbejde den militære kapacitet, hvorimod intentioner kan forandres natten over. Selv om Rusland ikke har umiddelbare intentioner om at anvende væbnet magt mod de baltiske lande, så er evnen til at besætte disse på ganske kort tid og afskære dem fra EUog NATO-støtte ikke kun tilstede, men har også været trænet under de to militære Zapad-øvelser. Ruslands mål i den baltiske region er formentlig ret forskellige fra målene med Ukraine. Hvor Rusland $ø$ nsker at lillebror - Ukraine - skal være en loyal og pålidelig partner, så er balterne ikke slavere og opfattes dermed som anderledes. I dette tilfælde ville det ideelle være, hvis de havde regeringer, der tog bestik af russisk udenrigspolitik, men stadig var medlemmer af både EU og NATO. Dette mål kan bedst opnås via en blød magtpolitik med en 'hård kant'.

Selvom de russiske militære reformer langt fra er færdige, er de tilstrækkelig udviklede til at vestlige sikkerhedsplanlæggere med stadig stigende bekymring ser på den russiske Anti-access/areal denial(A2AD) kapacitet i forbindelse med disses militære støtte til de baltiske stater. Dette var et område som indtil fornylig kun blev nævnt i i relation til Kina. Intentionen om at anvende væbnet magt i de baltiske stater er måske ikke aktuelt tilstede, men hvis kapaciteten er udviklet, så kan en forandring i omstændighederne (såsom et større udbrud af fjendtlighed i Stillehavet) som sagt forandre intentionen meget hurtigt.

Rusland har demonstreret sin parathed til at benytte sin militære magt med henblik på at opnå politiske mål og maksimal politisk kapital ud af frosne konflikter. Derfor er det ganske forståeligt, at de baltiske stater nødvendigvis må betragte Ruslands stadig voksende militære styrke og aggressive selvsikkerhed med bekymring. Når man i tillæg ser på Ruslands kapacitet til at kontrollere $s ø$ - og luftveje omkring Europa, så bliver vigtigheden af $\mathrm{A} 2 \mathrm{AD}$ endnu mere tydelig.

\section{Hvad skal man forvente af Putin?}

Skal vi forvente et andet slags angreb fra Rusland, måske en gentagelse af Donbas scenariet i Estlands Narva eller Letlands Latgale-region? Det er meget usandsynligt, fordi Kreml og den russiske generalstab ikke vil gentage, hvad der så tydeligt er mislykkedes i Ukraine. Selv om det for nylig er blevet umoderne at tale om blød magt, når Rusland udøver hård magt så ofte, så ville det være en fejl at overse denne form for magt, især i lande, der grænser op til Rusland. Mens 'Russkiy mir15' (den Russiske Verden) har slået fejl i Ukraine og RT (den engelsk sprogede TV-kanal Russia Today, red) ikke synes at gøre Rusland mere tiltalende internationalt, så har blød magt inden for SNG-landende og Baltikum stadig et vist potentiale.

Blød magt med en hård kant gør brug af den fælles sovjetiske historie, de russiske landsmænds indflydelse, russiske medier (især tv), det russiske sprog og populariteten af russisk kultur, historie og idræt. Men selv med den massive investe- 
ring i RT er det bemærkelsesværdigt, at Rusland, ifølge Pew Research, kun opfattes mere positivt end negativt $i$ tre lande: Kina, Vietnam og Ghana. Rusland benytter sig også rutinemæssigt af økonomiske håndtag til at fremme sin udenrigspolitik. Disse omfatter anvendelsen af misinformation, energi, penge og korruption som våben og dermed angribes demokratiske samfund indefra.

I tillæg til de traditionelle metoder for blød, økonomisk og hård magt har Rusland også udviklet en ny generation af asymmetriske eller ikke-lineære kompetencer som i Vesten normalt kaldes 'metoder for hybrid krigsførelse’. Formålet med disse er at udviske grænsen mellem krig og fred; mellem intern uro og ekstern aggression; mellem konventionel og nuklear konflikt - hvor især sidstnævnte er særlig farlig. Essensen er at gøre det, som ikke forventes. Derfor er der ingen blueprint for fremtidige aktioner. Krim og Donbas er ikke nødvendigvis modeller for fremtidige operationer.

\section{Er vi mere sikre?}

Ruslands handlinger er uforudsigelige. Putin er en opportunist, der har formået at overraske Vesten på Krim og nu i Syrien. Men denne formodede succes og Vestens manglende vilje til at konfrontere Rusland øger risikoen for fejlberegning med vidtrækkende konsekvenser.

Putins mål er at forblive ved magten så længe som muligt. På baggrund af de aktuelle økonomiske forhold og nedturen som følge heraf i selve Rusland kan dette bedst opnås ved at forfølge eksterne fjender. Putin så på, mens USSR gik i opløsning uden at et eneste skud blev affyret. Han vil gerne gøre det samme med NATO og EU.

For så vidt angår de baltiske lande, synes
Putins opmærksomhed at være andre steder. Men er vi mere sikre? Der er to synspunkter om Ruslands nuværende kapacitet i forbindelse med det syriske eventyr samtidig med, at Minsk-aftalerne ikke er blevet gennemført i Ukraine. Den første er, at Rusland har en så overvældende lokal konventionel overlegenhed, at Rusland kunne besætte de baltiske lande, når som helst Rusland har lyst til at gøre det. Det alternative synspunkt er, at Rusland ville være i stand til at angribe kritiske dele af de baltiske lande, men har ikke kræfter til holde stand i et fjendtligt miljø i længere tid. Dertil kommer, at det at administrere disse lande ville være problematisk og formentlig uden for Ruslands nuværende kapacitet. Men mest af alt vil de økonomiske konsekvenser af en militær konflikt med NATO være overvældende for den skrantende russiske økonomi, både i form af alvorlige sanktioner og andre direkte og indirekte omkostninger.

Samtidig skal det bemærkes, at de kommende måneder vil være en periode med øget risiko, præget af at præsident Obama primært vil bekymre sig om sit omdømme for eftertiden og derfor vil forsøge at undgå direkte konfrontation med Rusland frem til den nye amerikanske præsident påbegynder sin præsidentperiode. Heller ikke udsigten til Ruslands eget valg til Dumaen og præsidentvalget bør forblive ubemærket. Disse kan have en direkte rolle i udformningen af Putins opportunistiske udenrigspolitik.

Kremls fremtidige politik vil også formes af begivenheder i Syrien. For at beholde magten og aflede opmærksomheden fra interne problemer har Putin brug for eksterne succeser. Starten på den syriske offensiv indkasserede en kortvarig succes, men et varigt gennembrud synes så langt væk som nogensinde. Hvis 
Rusland ser sig selv hænge fast i Obamas hængedynd, så vil man søge efter et nyt fokus, der kan vende den russiske offentlighed væk fra vanskelighederne hjemme.

Hvor fokus rettes hen næste gang kan være vanskeligt at forudsige, men mulighederne for fejlberegning stiger med hvert nyt eventyr.

\section{Hvad skal vi gøre?}

Svaret på dette ligger i afskrækkelse. Afskrækkelse skal være i form af både konventionelle og ikke-konventionelle våben. Vi må forberede os på de værst tænkelige scenarier og skabe konventionel afskrækkelse, som er politisk, teknologisk og operationel troværdig. Dette er en ordentlig mundfuld og en, der ikke kan opnås med de nuværende forsvarsudgifter i Europa. Europa må også trække sin del og opretholde en teknologiske kapacitet, der kan fungere sammen med USA.

I forhold til ikke-konventionel afskrækkelse kræver dette udvikling af modstandsdygtighed mod propaganda, cyberangreb, undergravende virksomhed, væbnet infiltration og terrorangreb. Asymmetrisk pres bør mødes med en asymmetrisk reaktion. Vi er nødt til at finde nye måder at håndtere kriser og undgå, at vi går fejl af Rusland. Det bedste forsvar mod hybridkrig er legitim og effektiv regeringsførelse. Her bliver en klar ansvarsfordeling tydelig: NATO kan håndtere den totale militære udfordring, mens EU skal koncentrere sig om at levere regeringsal- ternativer til putinisme både hjemme og $\mathrm{i}$ vores region.

Vi skal identificere, hvad er vores, og hvad er Ruslands 'centre of gravity'. I Ruslands tilfælde kunne det være de politiske beslutningstagere og de indflydelsesrige. Men måske er det i lige så høj grad den russiske offentlighed og deres holdninger, som Kreml vier så meget opmærksomhed.

I vores eget tilfælde er sammenhold og solidaritet afgørende for, om vi får held med at skabe et mere forudsigeligt miljø. Vi bør opfylde vores selvforsvarsansvar over for NATO, herunder $\$ 3$ parallelt med, at vi forbereder vores kollektive forsvarsevne som beskrevet i $\$ 4$ og 5 .

Vi bliver også nødt til at se på måder, hvorpå vi kan hjælpe Rusland til at blive en normal stat efter Putin. Selvfølgelig kan det ske, at Putin bliver erstattet af en anden autokrat, men et kleptokratisk regime er sandsynligvis ikke i stand til at modstå forandring særlig længe i det 21. århundrede. Vi bør ikke endnu engang forpasse muligheden for at hjælpe Rusland til at blive en forudsigelig, demokratisk partner.

Det betyder, at vi allerede nu bør se efter måder at hjælpe Rusland med den næste transformation.

\section{(Oversat fra engelsk af Charlotte Flindt} Pedersen) 


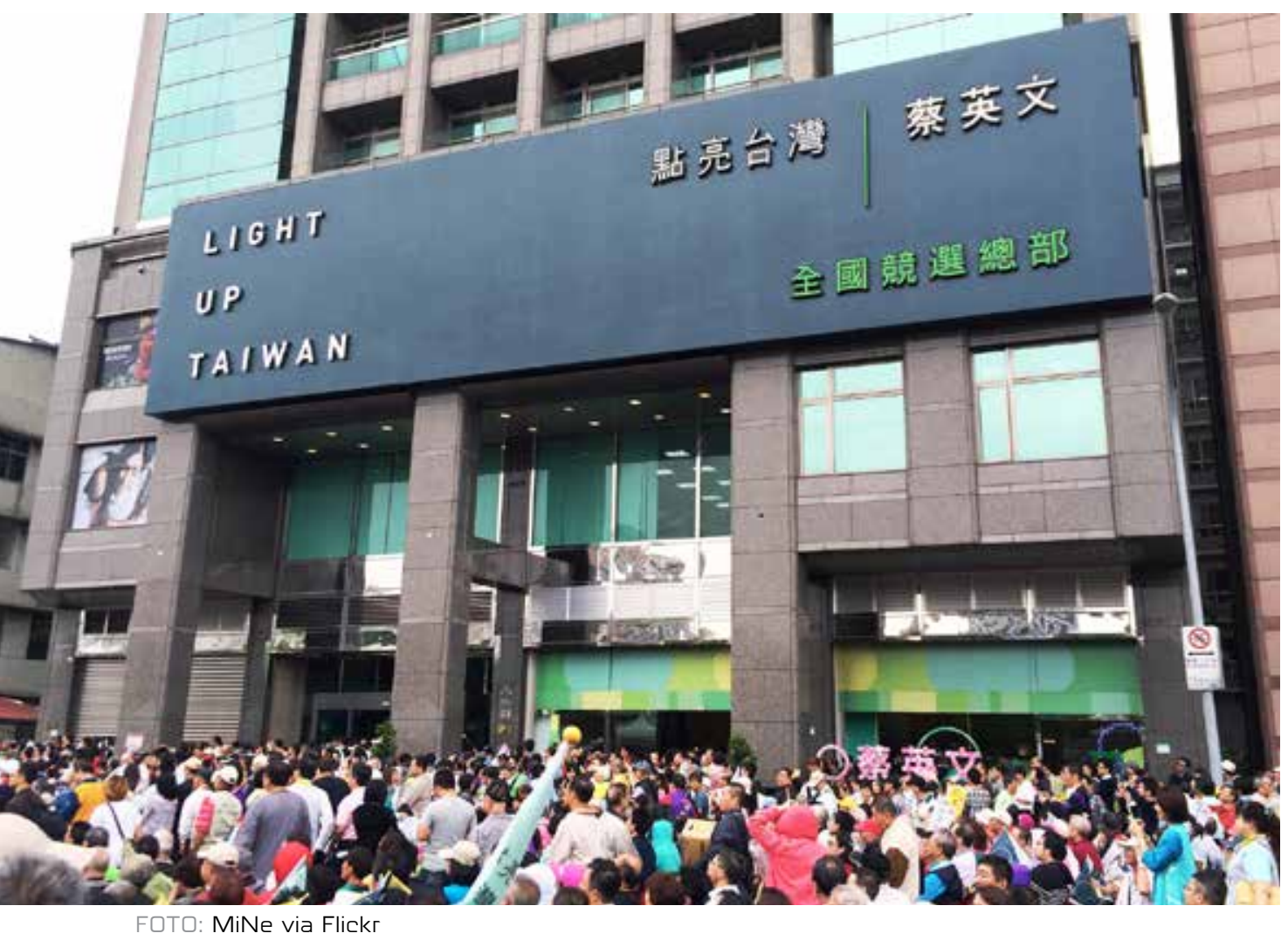

DPP's præsidentkandidat Tsai Ing-wen's kampagnehovedkvarter i hovedstaden Taipei. 